\title{
Angiotensin-Converting Enzyme inhibitors (ACE inhibitors) and Angiotensin II Receptor Blockers (ARBs) role in SARS-CoV-2 infection: A Rapid Systematic Review
}

Haliton Alves de Oliveira Junior ( $\nabla$ haoliveira@haoc.com.br)

Hospital Alemão Oswaldo Cruz - International Research Center https://orcid.org/0000-0002-0289-4947

Jessica Yumi Matuoka

Hospital Alemão Oswaldo Cruz - International Research Center https://orcid.org/0000-0002-7956-1606

Patrícia do Carmo Silva Parreira

Hospital Alemão Oswaldo Cruz - International Research Center https://orcid.org/0000-0002-7485-5429

Gabriela Vilela de Brito

Hospital Alemão Oswaldo Cruz - International Research Center https://orcid.org/0000-0002-6500-2213

Lays Pires Marra

Hospital Alemão Oswaldo Cruz - International Research Center https://orcid.org/0000-0002-6835-7749

Flávia Cordeiro de Medeiros

Hospital Alemão Oswaldo Cruz - International Research Center https://orcid.org/0000-0002-5305-8324

Álvaro Avezum Junior

Hospital Alemão Oswaldo Cruz - International Research Center https://orcid.org/0000-0002-3073-6890

\section{Systematic Review}

Keywords: COVID-19, SARS-CoV-2, Angiotensin-Converting Enzyme inhibitors, Angiotensin II Receptor Blockers, systematic review

Posted Date: April 9th, 2020

DOI: https://doi.org/10.21203/rs.3.rs-22273/v1

License: (c) (1) This work is licensed under a Creative Commons Attribution 4.0 International License. Read Full License 


\section{Abstract}

No medications specific treatments are known to be effective for COVID-19 until now. Several drug therapies are being used to optimize supportive care to relieve symptoms. Some observational and essentially theoretical studies have shared opposite opinions regarding the use of ACE inhibitors and ARBs in SARS-CoV-2 infected patients. Therefore, the aim of this review is to evaluate the relationship between ACE inhibitors and ARBs use and clinical effects in COVID-19 patients to guide clinicians for their medical early decision. Electronic searches were conducted on Embase, Medline via PubMed and ClinicalTrials.gov. Preferred Reporting Items for Systematic Reviews and Meta-Analyses (PRISMA) Statement was followed and adapted the research as a rapid review. Due to the emergency of the COVID19 pandemic, any research in English, Portuguese or Spanish that discuss the mechanism of action, in vitro studies and those that draw conclusions based on observational or experimental studies were included. No studies were excluded based on the participant's clinical or demographical characteristics. The risk of bias was assessed by one reviewer and checked by a second reviewer, using the Joanna Briggs Institute Checklist for Case Series. Any other mechanistic, theoretical or in vitro studies were evaluated as high risk of bias for clinical. Out of 64 studies retrieved, 17 were included in the review. Three studies suggest that both medications may increase the risk of worsening COVID-19, while three suggest they could be beneficial. Currently, there are seven ongoing trials on ARBs and ACE inhibitors. The available evidence does not allow us to draw definite conclusions on either harm or benefit of these medications in the presence of COVID-19. Discontinuing the therapy may be hasty and more robust evidence-based research is needed.

\section{Introduction}

Coronavirus infections are generally mild, however, the epidemics of severe acute respiratory syndrome coronavirus (SARS-CoV) ${ }^{1-3}$ and Middle East respiratory syndrome coronavirus (MERS-CoV) ${ }^{4,5}$ have caused more than 10,000 cumulative cases in the past two decades. ${ }^{6}$ Both prominent coronaviruses, 2002 SARS-CoV and 2012 MERS-CoV, have markedly affected humans, causing 8,422 and 1,600 infections, as well as 916 and 574 deaths, respectively. ${ }^{7-9}$ These viruses are categorized within the same genus of the subfamily Orthocoronavirinae within the family Coronaviridae. ${ }^{10}$

In December 2019, a group of patients with pneumonia of unknown cause was identified in Wuhan, in the Hubei province, China. ${ }^{10}$ High-throughput sequencing from lower respiratory tract samples indicated a novel coronavirus, named 2019 novel coronavirus (2019-nCoV) or, more recently, SARS-CoV-2, which had previously not been detected in humans or animals. ${ }^{6,9-11}$

Coronavirus Disease 2019 (COVID-19) common symptoms include fever, fatigue, and dry cough, followed by anorexia, myalgia and dyspnea. ${ }^{10,12-14}$ Chest imaging frequently shows bilateral infiltration. ${ }^{15} \mathrm{~A}$ case study with 1,099 COVID-19 patients in China found that the most common abnormalities found on computerized tomography (CT) scans were ground-glass opacity and bilateral patchy shadowing. ${ }^{13}$ 
As of March $30^{\text {th }}$, The World Health Organization (WHO) had been notified of 693,282

confirmed cases, from which 58,469 were notified in the last 24 hours. Furthermore, until the same date 33106 deaths were registered, and 3,215 occurred in the last 24 hours. Among these confirmed new cases, 987 (23 deaths) were in the Western Pacific Region, 31,784 (2,535 deaths) in Europe, 375 (19 deaths) in South-East Asia Region, 3,552 (145 deaths) in Eastern Mediterranean Region, 21,289 (484 deaths) in the Americas, and 482 (nine deaths) in Africa. According to WHO, these situations are classified as very high risk at a global level. ${ }^{16}$ Currently, other countries outside China and Europe, like the U.S.A., Canada, and Brazil are experiencing an accentuated growth in COVID-19 cases and deaths. Until March $30^{\text {th }}$, The Brazilian Ministry of Health confirmed 4,579 cases and 154 deaths since the first case registered on February $25^{\text {th }} \cdot 17,18$ In the USA, there were 122,653 confirmed cases and 2112 deaths until March $30^{\text {th }} .16$

Case series and other observational data regarding aggravation and risk of Acute Respiratory Distress Syndrome (ARDS) and death related to SARS-CoV-2 infection have been published. ${ }^{6,9,23,24,12-15,19-22}$ Some of these studies investigated factors specifically related to Intensive Care Unit (ICU) admission. ${ }^{6,9,12}$ According to recent publications, some clinical characteristics and comorbidities as age, presence of diabetes, hypertension, cardiovascular disease, elevated Sequential Organ Failure Assessment (SOFA) score, and serum D-dimer, lead to an increased risk of aggravation and death. ${ }^{15,19}$

Therefore, there is raising concern regarding COVID-19 patients with such comorbidities. Patients with diabetes have higher expression of Angiotensin-Converting Enzyme 2 (ACE-2) receptor as well as hypertensive patients treated with ACE inhibitors or Angiotensin II Receptor Blockers (ARBs). ${ }^{25}$ According to a Chinese case series, the plasma levels of Angiotensin II in 2019-nCoV infected patients were significantly higher than those of healthy individuals. ${ }^{26}$ In addition, the level of angiotensin II in patients with nCoV-2019 was strongly associated with viral load and lung injury, suggesting that the imbalance of the renin-angiotensin system (RAS) in patients is related to 2019-nCoV. The mechanism of infection by SARS-CoV-2 appears to be related to a glycoprotein, called Spike, which is responsible for the entry of viruses into host cells. The receptor binding domain (RBD) in the Spike molecule directly binds the receptors on the surface of host cells. In the case of SARS-CoV and bat-type-CoV, the receptor is ACE-2. As a result, it has been speculated that ACE-2 plays an important role in the pathogenesis of SARS-CoV- $2 .{ }^{27}$

Some observational and essentially theoretical studies have shared opposite opinions on this issue, mainly regarding the use of ACE inhibitors and ARBs. ${ }^{25-28}$ Some of them postulate that the increase in ACE- 2 receptors caused by ACE inhibitors and ARBs could increase the viral load. ${ }^{25,27}$ On the other hand, some authors believe that due to the increase in angiotensin II in 2019-nCoV infected subjects and the augmented lung permeability, the use of ACE inhibitors and ARBs could be an adjuvant for recovering of pneumonia. ${ }^{26,28}$

Our aim is to evaluate the relationship between ACE inhibitors and ARBs use and clinical effects in nCoV2019 infected patients, by means of a systematic rapid review, which could guide clinicians for their 
medical early decision, since clear and reliable evidence is not yet available.

\section{Methods}

\section{Study design}

We conducted a systematic rapid review to evaluate the risks and benefits of using ACE inhibitors and ARBs in SARS-CoV-2 infected patients. The current analysis was a response to the need for scientific evidence to support the compilation of a COVID-19 guideline for the German Hospital Oswaldo Cruz in São Paulo, Brazil, one of the Brazilian Excellence hospitals and, consequently, one of the hospitals with many confirmed cases of COVID-19.

We did not register any protocol at PROSPERO database due to the urgency of this issue and to the warning of PROSPERO regarding a delay in reviews for protocol approval. However, the research question that guides this study was formulated before conducting any review. We also followed the Preferred Reporting Items for Systematic Reviews and Meta-Analyses (PRISMA) Statement ${ }^{29}$ and adapted the research as a rapid review according to Tricco et al., 2017. ${ }^{30}$

\section{Eligibility Criteria}

Due to the emergency of the COVID-19 pandemic and the low certainty of evidence, we considered eligible any research that discuss the mechanism of action, in vitro studies and those that draw conclusions based on observational or experimental studies regarding the use of ACE inhibitors or ARBs in COVID-19 patients. We considered studies published in English, Portuguese or Spanish.

In vitro studies, pharmacodynamic studies, and state-of-the-art reviews about COVID-19, without necessarily being linked to the disclosure of relevant clinical information were excluded. No studies were excluded based on the participant's clinical or demographical characteristics.

Data selection, extraction and methodological assessment quality were performed by one reviewer and checked by a second reviewer. Any disagreement was solved by consensus.

\section{Research question}

As there is a lack of evidence on comparative effectiveness, it was not suitable to format our question following PICO acronym. In this way, and to run a sensitive search, we adopted only "P" and "I". Thus, our aim is to approach all the evidence of ACE inhibitors and ARBs use in patients with COVID-19, independently if the use was for primary disease (i.e. cardiovascular disease, hypertension, etc.) or as a treatment for COVID-19.

Source of evidence and Search Strategy 
Medline (via PubMed) and Embase were searched on March $20^{\text {th }}$ and ClinicalTrials.gov on March $23^{\text {rd }}$. Posteriorly, a search updating was conducted on March $31^{\text {st }}$. No validated or unvalidated filters were applied. We combined MeSH, entry terms, and word variations for "ACE inhibitors", "ARBs", and "COVID19/SARS-CoV-2", by means of the appropriate Boolean operator. In the clinical trials protocol registry database (ClinicalTrials.gov) we only selected evidence directly related to ACE inhibitors and ARBs as a therapeutic option for COVID-19. Any other health technology different from those were excluded, unless it was described as a comparator. The fully reproducible search strategies are described in Table 1.

\section{Risk of bias Assessment}

We planned to evaluate any epidemiological study and, since we did not insert any filter that could restrict data gathering, we could accomplish that. However, due to the scarcity of data in this particular period we could only find observational non-comparative data. Therefore, for case series we applied the Joanna Briggs Institute Checklist for Case Series. ${ }^{31}$ Nevertheless, following hierarchy of evidence, we consider case series a very weak and biased source of evidence. Any other mechanistic, theoretical or in vitro studies were evaluated as high risk of bias for clinical conclusions.

\section{Ethics Compliance}

This study did not recruit patients or involve any personal data that required consent or Ethic's Board approval.

\section{Results}

\section{Search results}

Through search strategies on Medline (via PubMed) and Embase, 58 references were retrieved. Additionally, in a validation search in Google Scholar, ${ }^{32,33}$ two references were inserted through manual search. ${ }^{25,34}$ Seven clinical trial records specifically related to ACE inhibitors or ARBs were found on ClinicalTrials.gov. After removing duplicates, 64 references were evaluated by their titles and abstracts. Of these, 42 references were excluded, and 22 were evaluated by full text reading. Five reports were excluded after complete reading: four because they were opinion reports that mentioned therapeutic options in general, not specifying discussions about mechanisms of action or addressing any outcomes data or other results. ${ }^{35-38}$ One case report was also excluded ${ }^{39}$, because it presented a specific result for an endstage renal disease patient (Table 2). Thus, 17 studies were included in the current review: two case series, ${ }^{26,40}$ seven opinion/commentary reports, ${ }^{25,28,34,41-44}$ one in vitro study, ${ }^{27}$ and seven ClinicalTrials.gov registries. The ClinicalTrials.gov results will be discussed in detail below. The complete screening procedure is exhibited in Figure 1. 
Study characteristics, such as study design, population, brief results and methodological quality are exhibited in Table 3. Due to the essential descriptive characteristics of the included studies, results are presented in a narrative form.

Chen et al., 2020 evaluated the particularities of the SARS-CoV-2 surface and possible structures related to its transmission capacity. ${ }^{27}$ The authors analyzed the genomic sequence of nCoV-2019 deposited by Wang et al., 2020. ${ }^{45}$ As mentioned by the authors, a glycoprotein, named Spike, is responsible for the entry of viruses in host cells. The receptor binding domain (RBD) in the Spike molecule directly binds the receptors on the surface of host cells. In the case of SARS-CoV and bat-type-CoV, the receptor is ACE-2. As a result, they speculate that ACE-2 plays an important role in the pathogenesis of SARS-CoV-2.

Diaz, 2020 postulates that ACE-2 receptors serve as binding sites for SARS-CoV-2 virions in the lungs. Therefore, patients taking ACE inhibitors and ARBs may be at increased risk for severe disease outcomes due to SARS-CoV-2 infections. The author exemplifies his point of view based on Chinese studies, which showed that patients with nCoV-2019 who had more severe conditions also had hypertension, cardiovascular diseases, diabetes, among other diseases, for which ACE inhibitors and ARBs are frequently prescribed. ${ }^{44}$

A commentary discusses the idea of considering angiotensin receptor 1 (AT1R) blockers as a provisional treatment for SARS-CoV-2 infections and proposes a research direction based on modeling data from patient clinical records to assess its feasibility. The author postulates that the use of ARBs causes an increase in the concentration of circulating ACE based on examples in mice and humans. In this sense, the author adds that, being aware that ACE is the main link between SARS-CoV-2 and the cell, the suggestion to treat patients with SARS with AT1R antagonists, to increase their expression of ACE-2, seems counterintuitive. ${ }^{28}$

Danser et al., 2020 presented a narrative review that indicates that there is there is no evidence to abandon renin-angiotensin system blockers. ${ }^{42}$ They discussed that, as previously shown in previous studies, ACE-2 is the receptor responsible for SARS coronavirus entry and that binding to the ACE-2 receptor requires the surface unit of a viral spike protein. Additionally, it was discussed that because of this incipient assumption, much confusion started, with controversial opinions and great fear about the influence of cardiovascular comorbidities and their respective treatments on the pathogenicity of COVID19.42

Sparks et al., 2020 expose the mechanistic and biochemical perspectives on the interaction between SARS-CoV-2 and ACE-2. The authors analyze the molecular aspects that may explain the benefits and harms of using ACE inhibitors and ARBs in the treatment of patients with cardiovascular diseases and COVID-19. Because of the lack of adjustment by confounders, the authors conclude that a clear relationship between hypertension and increased COVID-19 morbidity is premature. The authors recommend that those patients who use antihypertensive drugs for cardiovascular diseases do not interrupt the use, as there is still no evidence to support it. ${ }^{41}$ 
One viewpoint paper discusses that, despite the increased mortality and morbity in COVID-19 hypertensive patients, no study have checked this assumption when controlling for confounding. ${ }^{43}$ Thus, it remains unclear if this association is related to the pathogenesis of hypertension or another associated comorbidity or treatment. The authors postulate that there has been a growing concern that this association with hypertension is confounded by ACEl inhibitors and ARBs use. The link with these medications is because of the known association between angiotensin-converting enzyme 2 (ACE2) and SARS-CoV- $2 .{ }^{43}$

In a Chinese case series, respiratory samples from patients, including throat smears and bronchoalveolar fluid (BALF), were collected and real-time PCR was used to confirm the 2019-nCoV infection. The authors assessed potential biomarkers of disease severity. They found an elevated level of serum angiotensin II in patients with nCoV 2019 and this was strongly associated with viral load and lung injury, suggesting that the imbalance of the renin-angiotensin system (RAS) in patients was caused by $2019-n C o V$ and that enzyme-inhibiting drugs such as ACE inhibitors and ARBs, that balance RAS, can be used to treat patients infected with 2019-nCoV. ${ }^{26}$

Fang et al., 2020 explain that patients with diabetes have a higher expression of ACE-2 as well as hypertensive patients treated with ACE inhibitors or ARBs. According to the authors, as the virus uses ACE2 to replicate, having the aforementioned comorbidities and using ACE inhibitors and ARBs may contribute to the pathogenicity of SARS-CoV2. ${ }^{25}$

Guo et al., 2020 conducted a case series of 187 patients with COVID-19, 77\% of whom were discharged and another $23 \%$ died. ${ }^{40}$ These patients were evaluated at the Seventh Hospital of Wuhan City, China and $63(35.3 \%)$ had some cardiovascular disease such as hypertension, coronary heart disease, cardiomyopathy, and 52 (27.8\%) had myocardial damage indicated by high levels of troponin T (TnT). This study showed that patients with high levels of TnT were elderly, had more comorbidities, higher proportion of SARS, higher mortality, higher white blood cell count, neutrophilia, high level of D-dimer and higher concentration of inflammatory markers than individuals with normal TnT level. Despite reporting that there is a greater proportion of patients using ACE inhibitors and ARBs among those with high TnT, the authors states that there was no difference in mortality between these groups. ${ }^{40}$

Vaduganathan et al., 2020 is a narrative review that discusses potential benefits and harms of ReninAngiotensin-Aldosterone System Inhibitors (RAAS) in Patients with Covid-19. ${ }^{34}$ These paper gathers in vitro, animal models, other respiratory viruses and recent COVID-19 research data. The authors highlight that the data in humans are too limited to support or refute the hypotheses of harm (raise of viral load) or benefit (downregulation of angiotensin II) of the RAAS. They discuss the lack of clinical tests of RAAS blockers on ACE-2 levels and activity in humans, stating that ACE-2 may be beneficial rather than harmful in patients with lung injury patients, not only COVID-patients. Finally, they discuss that withdrawal of RAAS inhibitors may be harmful in certain high-risk patients with known or suspected Covid-19. ${ }^{34}$ 
The majority of the studies were comments, opinions and in vitro studies. Regarding the usefulness of data in the context of clinical decision, these reports should be interpreted with caution. Furthermore, only two study in humans were found. ${ }^{26,40}$ These case series, according to JBI Critical Appraisal Tool for case series, were classified as having moderate ${ }^{26}$ and good ${ }^{40}$ methodological quality, respectively. We emphasize that this classification does not put the evidence from case series close to that of comparative observational or randomized studies and that the confidence in this evidence is low (Table 4).

\section{Clinical trials protocols}

Seven records of clinical trials involving ACE inhibitors, ARBs and recombinant ACE-2 therapy were found in the ClinicalTrials.gov database (Table 5). Two Randomized Controlled Trials (RCT) registries propose to evaluate losartan versus placebo (NCT04303299 and NCT04311177). These registries are not yet recruiting and have primary estimated completion date for March and April 2021, respectively. Two case control registries intend to compare outcomes of patients with confirmed COVID-19 pneumonia treated and not treated with ACE inhibitors or ARBs (NCT04318301 and NCT04318418). These observational studies have estimated primary completion date for March and April 2020, respectively. One RCT intends to evaluate the combination of lopinavir/ritonavir or hydroxychloroquine or losartan plus standard care versus placebo plus standard care in hospitalized adults with COVID-19 (NCT04328012). Two studies initially registered on this database were recently withdrawn. One would evaluate replacement with recombinant human angiotensin-2 converting enzyme associated with conventional treatment versus conventional treatment only and was withdrawn for not obtaining Center for Drug Evaluation approval (NCT04308668). The other study was a cohort study that would evaluate outcomes of hypertensive patients with COVID-19 pneumonia receiving or not ACE inhibitors treatment. It was withdrawn due to the existence of similar studies registered at the present date (NCT04272710).

\section{Discussion}

After the publication of Fang et al., 2020, ${ }^{25}$ in which the authors discussed the potential harms in the use of ACE inhibitors, ARBs and some anti-inflammatory drugs, as ibuprofen in COVID-19 patients, much has been said about the care for the diabetic, hypertensive and cardiovascular population, as there is a potential risk in the use of these drugs for these comorbidities.

The primary WHO recommendation was to avoid the use of ibuprofen was based on concerns raised by French officials, who cited the above-mentioned study. Currently, some institutions like Health Canada, European Medicines Agency and The UK government published that there is no scientific evidence establishing a link between ibuprofen and worsening of COVID-19. Therefore, they recommend that subjects who currently use any NSAIDs to treat their chronic diseases should not stop their treatment and 
seek for specialized information. ${ }^{46-48}$ These events drew our attention to the need to assess the role of ACE inhibitors and ARBs in COVID-19 pathogenesis.

Fang et al., 2020 point out that, in different reports, patients who presented with severe forms of disease, had comorbidities frequently treated with ACE inhibitors or ARBs. ${ }^{25}$ However, none of them assessed the use of those medications in their cohorts or verified their association with disease severity or other outcomes. ${ }^{13,49,50}$ Additionally, their assumption that those medications pose significant harm to COVID19 pneumonia patients is based on the hypothesis of an upregulation of ACE-2, to which SARS-CoV-2 binds. However, the response of an individual does not depend solely on the exposure to ACE inhibitors or ARBs $^{25}$.

The available evidence is conflicting, given the weak methodological quality of the scientific evidence and the heterogeneous assumptions presented by the studies. Among evaluated studies, three ${ }^{25,27,44}$ highlight the fact that SARS-CoV-2 binds to ACE-2 receptors, increases its capacity for dissemination and, consequently, increases its pathogenicity. Thus, they emphasized that patients with cardiovascular comorbidities and/or using ACE inhibitors and ARBs may have a higher risk of worsening with COVID-19.

On the other hand, some studies ${ }^{26,28,34}$ suggest that infected patients present an increase in the concentration of angiotensin II, increasing pulmonary permeability and, consequently, the pathogenicity of COVID-19. These authors suggest that ACE inhibitors and ARBs may be therapeutic options for SARSCoV2, as they lead to decreased angiotensin II concentration and reduced pulmonary permeability.

Indeed, there are some research pointing that there is no evidence to interrupt or withhold treatment with ACE inhibitors or ARBs in COVID-19 patients who also present cardiovascular comorbidities. ${ }^{34,41-43}$ These studies jointly analyze the pathways that suggest benefits and harms of ACE inhibitors and ARBs and conclude that no strong adjustments by confounders have been made, and that comorbidities themselves or other factors strongly associated with the COVID-19 condition, such as age, need to be better assessed.

Two studies showed results from tests on humans, ${ }^{26,40}$ both are case series one with $12^{26}$ and the other with $187^{40}$ Chinese patients with COVID-19. Liu et al., 2020 found an increased level of angiotensin II in those patients, which was associated with viral load and lung injury. According to the authors, considering this RAS imbalance, those patients, potentially, could benefit from drugs that regulate this system, like ACE inhibitors and ARBs. ${ }^{26}$ Guo et al., 2020 found that patients with higher levels of troponin T presented more comorbidities, were aged, were using more frequently ACE inhibitors and ARBs and showed an increase in biochemical inflammatory biomarkers. However, there was no difference in mortality between those treated and not treated with ACE inhibitors or ARBs. ${ }^{40}$. Therefore, it is possible to infer that there are still some doubts about how much the severity of COVID-19 may be related to the use of ACE inhibitors or ARB or to the very complications of the age group or comorbidities.

Additionally, the American, European and Brazilian cardiology societies, ${ }^{51-53}$ the latter endorsed by the Brazilian Ministry of Health, ${ }^{54}$ published statements in which they highlighted the weak evidence 
available so far, and that any decision of avoiding ACE inhibitors and ARBs therapies is hasty. These Medical Societies also recommended that best care practices being observed to ensure the effectiveness of treatments, until more robust data can prove the true effect of SARS-CoV-2 on the ACE-2 receptor mechanism, as well as the role of ACE inhibitors and ARBs in pathogenesis of SARS-CoV-2.

Much of the available evidence on the use of ACE inhibitors and ARBs still lie in theoretical grounds, based on molecular assays, animal studies and the previous experience with other coronaviruses infections.

To date, there are no studies with ARBs and ACE inhibitors in patients with COVID-19 in terms of comparative efficacy, comparing both active treatments, one active treatment vs. placebo or supportive measures, or no treatment. Furthermore, answers to these medicines' effectiveness is not about to be published. According to our search in ClinicalTrials.gov, there are only two registered RCT protocols with losartan versus placebo, both with preliminary results planned to 2021 (NCT04312009 and NCT04311177). There are also retrospective case-control studies registered that aims to evaluate outcomes of hypertensive patients with confirmed diagnosis of COVID-19 on ACE inhibitors or ARBs versus control. Their estimated completion date is March/April, 2020 (NCT04318301 e NCT04318418). More recently, a new RCT have been registered, and it aims to compare the efficacy of different medication (lopinavir/ ritonavir or hydroxychloroquine or losartan compared to placebo on disease severity. This study is expected to be completed in April, 2021 (NCT04328012).

Our review has some important limitations, most of them related to the weak quality of the evidence found. The whole evidence is observational and most of it purely theoretical and descriptive, and no study has ever evaluated the ACE inhibitors and ARBs effectiveness in the context of clinical research or comparative randomized or non-randomized studies.

We conducted a systematic rapid review, as proposed by Tricco et al., 2017,30 due to the urgency of response. We had to save time and, therefore, instead of conducting the steps by independent reviewers, one author performed the steps and a second reviewer checked the data and the assessments. Nevertheless, we believe that the most relevant evidence published had been included in this research and that the omission of some systematic steps has not invalidated the results. We did not include evidence published in Chinese due to the language barrier, but we checked their abstracts in English and found that only one study which would be eligible. ${ }^{26}$ Finally, results should be interpreted cautiously, taking into account the presence of bias associated with the outcomes.

To our knowledge, this is the first systematic rapid review to compile the available evidence on the use of ACE inhibitors and ARBs in patients with COVID-19. We conducted a comprehensive systematic review, including different types of documents that evaluate the use of these medications in the context of SARSCoV-2 infection and contrasted with recommendations by different institutions, like medical societies and the WHO. 


\section{Conclusion}

Based on the currently available evidence, it is not possible to state that ACE inhibitors and ARBs are harmful or beneficial for patients with COVID-19. The Brazilian, European and American Cardiology Societies do not recommend the interruption of standard proven therapies and they recommend continuing adopting the best therapeutic practices, until more robust evidence, can say otherwise.

\section{Declarations}

\section{Acknowledgment}

\section{Funding}

This research was supported by public funds from the Brazilian Unified Health System Institutional Development Program (PROADI-SUS). Only the authors worked in this review. No external writing service or funder had any role in research design and results.

\section{Authorship}

HAOJ is the main author and paper organizer. He was the main reviewer and worked with evidence screening, data analysis and paper writing and formatting. This author worked in the tables content and in the methodological quality judgement. JYM was the second reviewer responsible for checking and updating all the evidence, paper writing and formatting, including the tables and figure. PP, LPM, FM and GVB contributed to the study concept and design, participated in the final review of the manuscript. AAJ is the Hospital's Research Manager and the responsible for planning the study and research question. $\mathrm{He}$ also supervised the whole review process.

All named authors meet the International Committee of Medical Journal Editors (ICMJE) criteria for authorship for this article, take responsibility for the integrity of the work as a whole, and have given their approval for this version to be published.

\section{Disclosures}

The authors have no conflicts to declare.

\section{Compliance with Ethics guidelines}

This study did not recruit patients or involve any personal data that required consent or Ethic's Board approval.

\section{Data Availability}

All the results and research methods are available in this publication. There is no additional scientific data to share. 


\section{References}

1 Ksiazek TG, Erdman D, Goldsmith CS, Zaki SR, Peret T, Emery S, et al. A Novel Coronavirus Associated with Severe Acute Respiratory Syndrome. N Engl J Med. 2003 May;348(20):1953-66.

2 Kuiken T, Fouchier RAM, Schutten M, Rimmelzwaan GF, van Amerongen G, van Riel D, et al. Newly discovered coronavirus as the primary cause of severe acute respiratory syndrome. Lancet (London, England). 2003 Jul;362(9380):263-70.

3 Drosten C, Gunther S, Preiser W, van der Werf S, Brodt H-R, Becker S, et al. Identification of a novel coronavirus in patients with severe acute respiratory syndrome. N Engl J Med. 2003 May;348(20):196776.

4 Zaki AM, van Boheemen S, Bestebroer TM, Osterhaus ADME, Fouchier RAM. Isolation of a novel coronavirus from a man with pneumonia in Saudi Arabia. N Engl J Med. 2012 Nov;367(19):1814-20.

5 de Groot RJ, Baker SC, Baric RS, Brown CS, Drosten C, Enjuanes L, et al. Middle East respiratory syndrome coronavirus (MERS-CoV): announcement of the Coronavirus Study Group. J Virol[Internet]. 2013/05/15. 2013 Jul;87(14):7790-2. Available from: https://pubmed.ncbi.nlm.nih.gov/23678167

6 Huang C, Wang Y, Li X, Ren L, Zhao J, Hu Y, et al. Clinical features of patients infected with 2019 novel coronavirus in Wuhan, China. Lancet (London, England). 2020 Feb;395(10223):497-506.

7 Chan KS, Zheng JP, Mok YW, Li YM, Liu YN, Chu CM, et al. SARS: prognosis, outcome and sequelae. Respirology. 2003 Nov;8 Suppl:S36-40.

8 Badawi A, Ryoo SG. Prevalence of Diabetes in the 2009 Influenza A (H1N1) and the Middle East Respiratory Syndrome Coronavirus: A Systematic Review and Meta-Analysis. J Public health Res. 2016 Dec;5(3):733.

9 Li B, Yang J, Zhao F, Zhi L, Wang X, Liu L, et al. Prevalence and impact of cardiovascular metabolic diseases on COVID-19 in China. Clin Res Cardiol. 2020;

10 Xu X-W, Wu X-X, Jiang X-G, Xu K-J, Ying L-J, Ma C-L, et al. Clinical findings in a group of patients infected with the 2019 novel coronavirus (SARS-Cov-2) outside of Wuhan, China: retrospective case series. BMJ. 2020 Feb;368:m606.

11 WHO. Clinical management of severe acute respiratory infection when novel coronavirus (nCoV) infection is suspected. 2020.

12 Wang D, Hu B, Hu C, Zhu F, Liu X, Zhang J, et al. Clinical Characteristics of 138 Hospitalized Patients With 2019 Novel Coronavirus-Infected Pneumonia in Wuhan, China. JAMA. 2020 Feb; 
13 Guan W-J, Ni Z-Y, Hu Y, Liang W-H, Ou C-Q, He J-X, et al. Clinical Characteristics of Coronavirus Disease 2019 in China. N Engl J Med. 2020 Feb;

14 Chen N, Zhou M, Dong X, Qu J, Gong F, Han Y, et al. Epidemiological and clinical characteristics of 99 cases of 2019 novel coronavirus pneumonia in Wuhan, China: a descriptive study. Lancet (London, England). $2020 \mathrm{Feb} ; 395(10223): 507-13$.

15 Wu C, Chen X, Cai Y, Xia J, Zhou X, Xu S, et al. Risk Factors Associated With Acute Respiratory Distress Syndrome and Death in Patients With Coronavirus Disease 2019 Pneumonia in Wuhan, China. JAMA Intern Med. 2020 Mar;

16 WHO. Coronavirus disease 2019 (COVID-19) Situation Report - 63. 2020.

17 World Health Organization. Coronavirus disease (COVID-2019) situation reports. 2020.

18 BRASIL. Ministério da Saúde. Painel Coronavírus [Internet]. 2020 [cited 2020 Mar 31]. Available from: https://covid.saude.gov.br/

19 Zhou F, Yu T, Du R, Fan G, Liu Y, Liu Z, et al. Clinical course and risk factors for mortality of adult inpatients with COVID-19 in Wuhan, China: a retrospective cohort study. Lancet (London, England). 2020 Mar;

20 Xie J, Tong Z, Guan X, Du B, Qiu H, Slutsky AS. Critical care crisis and some recommendations during the COVID-19 epidemic in China. Intensive Care Med. 2020 Mar;

21 Wang J, Qi H, Bao L, Li F, Shi Y. A contingency plan for the management of the 2019 novel coronavirus outbreak in neonatal intensive care units. Lancet Child Adolesc Heal. 2020 Apr;4(4):258-9.

22 Wang L, Shi Y, Xiao T, Fu J, Feng X, Mu D, et al. Chinese expert consensus on the perinatal and neonatal management for the prevention and control of the 2019 novel coronavirus infection (First edition). Ann Trans/ Med. 2020 Feb;8(3):47.

23 Liao X, Wang B, Kang Y. Novel coronavirus infection during the 2019-2020 epidemic: preparing intensive care units-the experience in Sichuan Province, China. Intensive Care Med. 2020 Feb;46(2):35760 .

24 Bouadma L, Lescure F-X, Lucet J-C, Yazdanpanah Y, Timsit J-F. Severe SARS-CoV-2 infections: practical considerations and management strategy for intensivists. Intensive Care Med. 2020 Feb;

25 Fang L, Karakiulakis G, Roth M. Are patients with hypertension and diabetes mellitus at increased risk for COVID-19 infection? The Lancet. Respiratory medicine. England; 2020.

26 Liu Y, Yang Y, Zhang C, Huang F, Wang F, Yuan J, et al. Clinical and biochemical indexes from 2019nCoV infected patients linked to viral loads and lung injury. Sci China Life Sci. 2020 Mar;63(3):364-74. 
27 Chen Y, Guo Y, Pan Y, Zhao ZJ. Structure analysis of the receptor binding of 2019-nCoV. Biochem Biophys Res Commun. 2020 Feb;

28 D. G. Angiotensin receptor blockers as tentative SARS-CoV-2 therapeutics. Drug Dev Res. 2020;

29 Moher D, Liberati A, Tetzlaff J, Altman DG, Group TP. Preferred Reporting Items for Systematic Reviews and Meta-Analyses: The PRISMA Statement. PLOS Med. 2009 Jul;6(7):e1000097.

30 Tricco AC, Langlois E V, Straus SE, Research A for HP and S, Organization WH. Rapid reviews to strengthen health policy and systems: a practical guide. Geneva PP - Geneva: World Health Organization;

31 The Joanna Briggs Institute. The Joanna Briggs Institute Critical Appraisal tools for use in JBI Systematic Reviews Checklist for Case Series. 2017.

32 Piasecki J, Waligora M, Dranseika V. Google Search as an Additional Source in Systematic Reviews. Sci Eng Ethics. 2018;24(2):809-10.

33 Peralta-Pizza F, Pinzón DC, Gaitán HG, Eslava-Schmalbach J, Rodriguez-Malagon N. Google Scholar to identify research studies. Cochrane Database Syst Rev. 2019;(1).

34 Vaduganathan M, Vardeny O, Michel T, McMurray JJ V, Pfeffer MA, Solomon SD. ReninAngiotensin-Aldosterone System Inhibitors in Patients with Covid-19. N Engl J Med [Internet]. 2020 Mar 30; Available from: https://doi.org/10.1056/NEJMsr2005760

35 A. Z, D.S. H, E.I. A, Z.A. M, M. M. Reducing mortality from 2019-nCoV: host-directed therapies should be an option. Lancet. 2020;395(10224):e35-6.

36 Fedson DS, Opal SM, Rordam OM. Hiding in Plain Sight: an Approach to Treating Patients with Severe COVID-19 Infection. MBio. 2020 Mar;11(2).

37 Perico L, Benigni A, Remuzzi G. Should COVID-19 Concern Nephrologists? Why and to What Extent? The Emerging Impasse of Angiotensin Blockade. Nephron. 2020/03/24. 2020;1-9.

38 Marin GH. Facts and reflections on COVID-19 and anti-hypertensives drugs. Drug Discov Ther. 2020 Mar;

39 Ferrey AJ, Choi G, Hanna RM, Chang Y, Tantisattamo E, Ivaturi K, et al. A Case of Novel Coronavirus Disease 19 in a Chronic Hemodialysis Patient Presenting with Gastroenteritis and Developing Severe Pulmonary Disease. Am J Nephrol. 2020 Mar;1-6.

40 Guo T, Fan Y, Chen M, Wu X, Zhang L, He T, et al. Cardiovascular Implications of Fatal Outcomes of Patients With Coronavirus Disease 2019 (COVID-19). JAMA Cardiol. 2020 Mar;

41 Sparks MA, South A, Welling P, Luther JM, Cohen J, Byrd JB, et al. Sound Science before Quick Judgement Regarding RAS Blockade in COVID-19. Clin J Am Soc Nephrol. 2020 Mar; 
42 Danser AHJ, Epstein M, Batlle D. Renin-Angiotensin System Blockers and the COVID-19 Pandemic: At Present There Is No Evidence to Abandon Renin-Angiotensin System Blockers. Hypertens (Dallas, Tex 1979). 2020 Mar;HYPERTENSIONAHA12015082.

43 Patel AB, Verma A. COVID-19 and Angiotensin-Converting Enzyme Inhibitors and Angiotensin Receptor Blockers: What Is the Evidence? JAMA. 2020 Mar;

44 Diaz JH. Hypothesis: angiotensin-converting enzyme inhibitors and angiotensin receptor blockers may increase the risk of severe COVID-19. J Travel Med. 2020 Mar;

45 Wang C, Horby PW, Hayden FG, Gao GF. A novel coronavirus outbreak of global health concern. Lancet (London, England). 2020 Feb;395(10223):470-3.

46 Government U. Ibuprofen use and Coronavirus (COVID-19). 2020.

47 European Medicines Agency. EMA issues statement on ibuprofen reports relating to COVID-19. 2020.

48 Health Canada. Recalls and Safety alerts: No scientific evidence that ibuprofen worsens COVID-19 symptoms. 2020.

49 Yang X, Yu Y, Xu J, Shu H, Xia J, Liu H, et al. Clinical course and outcomes of critically ill patients with SARS-CoV-2 pneumonia in Wuhan, China: a single-centered, retrospective, observational study. Lancet Respir Med. 2020 Feb;

50 Zhang J-J, Dong X, Cao Y-Y, Yuan Y-D, Yang Y-B, Yan Y-Q, et al. Clinical characteristics of 140 patients infected with SARS-CoV-2 in Wuhan, China. Allergy. 2020 Feb;

51 Cardiology ES of. Position Statement of the ESC Council on Hypertension on ACE-Inhibitors and Angiotensin Receptor Blockers. 2020.

52 American College of Cardiology. HFSA/ACC/AHA Statement Addresses Concerns Re: Using RAAS Antagonists in COVID-19. 2020.

53 Sociedade Brasileira de Cardiologia. Infecção pelo Coronavírus 2019 (COVID-19). 2020.

54 Agência Brasil. Ministério da Saúde desaconselha Ibuprofeno para tratar Covid-19. 2020.

\section{Tables}

Table 1. Full electronic search strategies. 


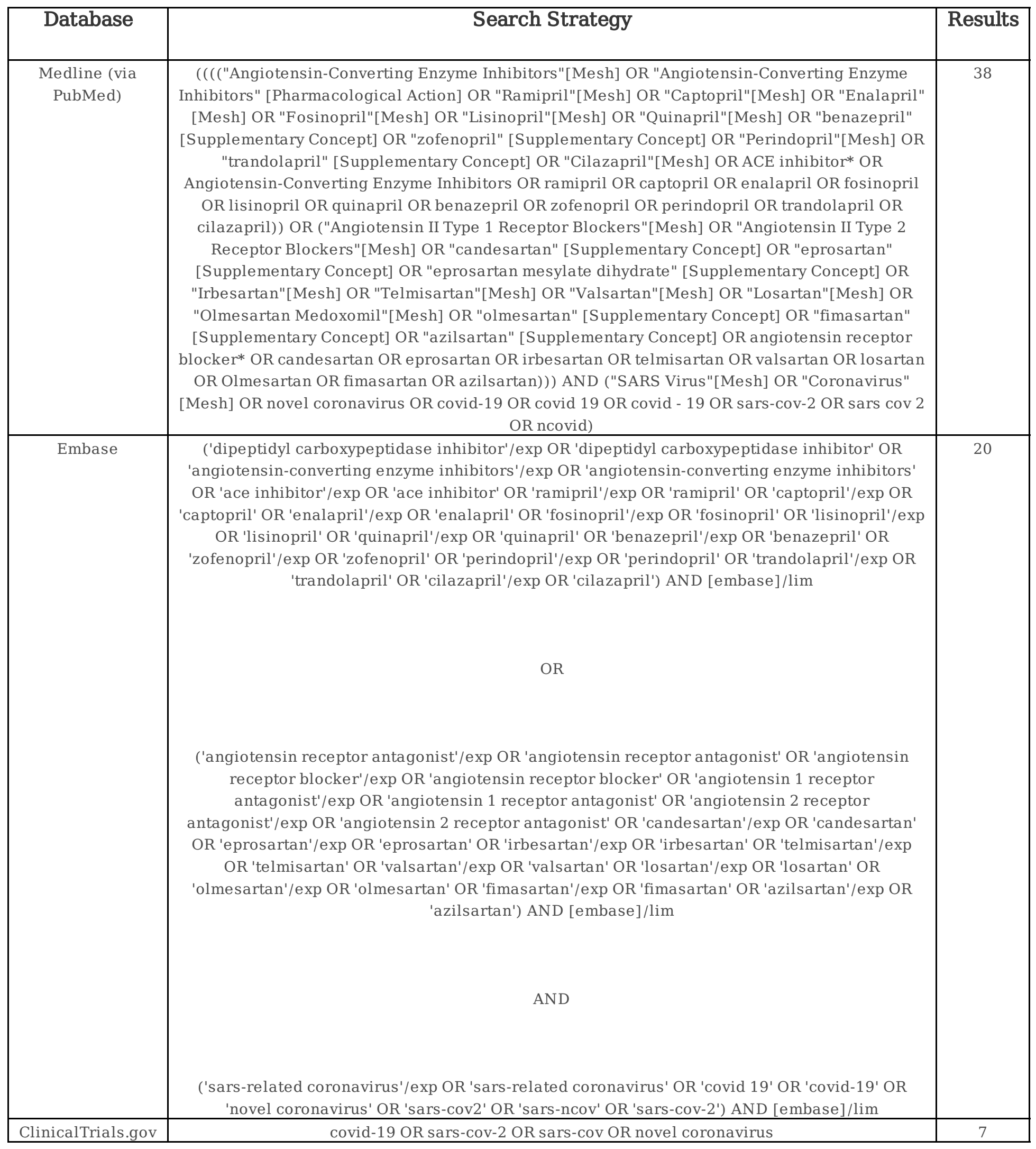

Table 2. Excluded study and reasons for exclusion. 


\begin{tabular}{|c|c|}
\hline Study & Reasons for exclusion \\
\cline { 1 - 1 } $\begin{array}{c}\text { Zumla et } \\
\text { al., 2020 }\end{array}$ & $\begin{array}{c}\text { Correspondences/opinion reports that addresses therapeutic options and do not present a discussion about their } \\
\text { mechanisms of action or their results (in vitro or clinical). }\end{array}$ \\
\cline { 1 - 1 } Marin 2020 & \\
\cline { 1 - 1 } $\begin{array}{c}\text { Fedson et } \\
\text { al., 2020 }\end{array}$ & \\
\cline { 1 - 1 } $\begin{array}{c}\text { Perico et } \\
\text { al., 2020 }\end{array}$ & \\
\cline { 1 - 2 } $\begin{array}{c}\text { Ferrey et } \\
\text { al., 2020 }\end{array}$ & $\begin{array}{l}\text { Case series reporting a patient with end-stage renal disease in whom losartan was withheld due to specific } \\
\text { aggravation. No additional information is given. }\end{array}$ \\
\hline
\end{tabular}

Table 3. Characteristics of the included studies and risk of bias assessment. 


\begin{tabular}{|c|c|c|c|c|}
\hline $\begin{array}{c}\text { Author/ } \\
\text { year }\end{array}$ & Study Design & Sample & Main results & $\begin{array}{c}\text { Risk of bias/ } \\
\text { methodological } \\
\text { quality }\end{array}$ \\
\hline $\begin{array}{l}\text { Chen et al., } \\
2020\end{array}$ & In vitro & NA & $\begin{array}{l}\text { When performing the molecular simulation, } \\
\text { the authors obtained a ternary structure for } \\
2019 \text {-nCoV that is almost fully } \\
\text { superimposable with that of SARS-CoV, } \\
\text { except for a structural variation observed in } \\
\text { a loop, which means the two cellular link } \\
\text { structures are very similar. } \\
\text { Amino acid residues at the RBD/ ACE-2 } \\
\text { binding interface play a crucial role in } \\
\text { determining binding affinity. As a result, } \\
\text { nCoV2019 has a stronger link with ACE } \\
\text { through the glycoprotein Spike, compared } \\
\text { with SARS-CoV. } \\
\text { The authors draw attention to the low } \\
\text { expression of ACE in the lungs, emphasizing } \\
\text { that the pathogenicity of nCoV2019 in this } \\
\text { organ may be due to the activity of specific } \\
\text { cells, but does not report which ones. They } \\
\text { also draw attention to the high expression of } \\
\text { ACE in the intestine and kidneys, meaning } \\
\text { SARS-CoV-2 can be present in the urine and } \\
\text { feces and that fecal-oral and body fluids } \\
\text { transmission cannot be ruled out. }\end{array}$ & High risk \\
\hline
\end{tabular}




\begin{tabular}{|c|c|c|c|c|}
\hline $\begin{array}{c}\text { Author/ } \\
\text { year }\end{array}$ & Study Design & Sample & Main results & $\begin{array}{c}\text { Risk of bias/ } \\
\text { methodological } \\
\text { quality }\end{array}$ \\
\hline $\begin{array}{l}\text { Danser et al., } \\
2020\end{array}$ & $\begin{array}{l}\text { Narrative } \\
\text { review/opinion }\end{array}$ & NA & $\begin{array}{l}\text { The authors suggest there is evidence from } \\
\text { animal studies that } \\
\text { ARBs may upregulate membrane-bound } \\
\text { ACE-2, whereas ACE } \\
\text { inhibitors may not. Even if the reported } \\
\text { upregulation of tissue ACE-2 by ARBs in } \\
\text { animal studies, and generally with high } \\
\text { doses, could be extrapolated to humans, it is } \\
\text { unclear whether it would be enough to } \\
\text { facilitate SARS-CoV-2 entry. Furthermore, it } \\
\text { is mentioned that ACE2 expression by } \\
\text { continuous treatment with ARBs may } \\
\text { actually be protective in the course of SARS- } \\
\text { CoV-2 infection, because ARBs upregulate } \\
\text { ACE-2 expression, decreasing angiotensin II } \\
\text { levels and reducing lung injury. } \\
\text { Finally, based in the current evidence, the } \\
\text { authors strongly recommend against the } \\
\text { withdrawal of ACE inhibitors and ARBs in } \\
\text { COVID-19 patients with hypertension or } \\
\text { other CVD. }\end{array}$ & High risk \\
\hline Diaz, 2020 & Letter & NA & $\begin{array}{l}\text { The author postulates that since patients } \\
\text { treated with ACE inhibitors and ARBs will } \\
\text { have an increased number of ACE-2 } \\
\text { receptors in the lungs. SARS-CoV-2 binds to } \\
\text { these receptors through their Spike } \\
\text { proteins, it may in increased risk of severe } \\
\text { disease results due to SARS-CoV-2. } \\
\text { Additionally, the author recommends: } \\
\text { "Patients treated with ACE inhibitors and ARBs } \\
\text { for cardiovascular diseases should avoid } \\
\text { crowds, mass events, ocean cruises, prolonged } \\
\text { air travel and all people with respiratory } \\
\text { illnesses during the current outbreak of COVID- } \\
\text { 19, in order to reduce their risks of infection". }\end{array}$ & High risk \\
\hline
\end{tabular}




\begin{tabular}{|c|c|c|c|c|}
\hline $\begin{array}{c}\text { Author/ } \\
\text { year }\end{array}$ & Study Design & Sample & Main results & $\begin{array}{c}\text { Risk of bias/ } \\
\text { methodological } \\
\text { quality }\end{array}$ \\
\hline Gurwitz 2020 & Commentary & NA & $\begin{array}{l}\text { The author explains that SARS-CoV-2 binds } \\
\text { to ACE-2 by the protein Spike and causes a } \\
\text { reduction in the activity of ACE-2 and, } \\
\text { consequently, a greater production of } \\
\text { angiotensin. It results in greater pulmonary } \\
\text { permeability, increasing the pathogenicity of } \\
\text { the virus. That is, for the author, using ARBs } \\
\text { causes the blockage of the excessive } \\
\text { activation of angiotensin-mediated AT1R } \\
\text { caused by viral infection, as well as } \\
\text { increasing the activity of ACE-2, thus } \\
\text { reducing the production of angiotensin by } \\
\text { ACE and increasing the production of } \\
\text { vasodilator angiotensin } 1-7 .\end{array}$ & High risk \\
\hline $\begin{array}{l}\text { Liu et al., } \\
2020\end{array}$ & Case series & $\begin{array}{l}12 \text { patients, eight } \\
\text { men, seven over } 60 \\
\text { years of age. These } \\
\text { patients came from } \\
\text { Shenzhen Third } \\
\text { People's Hospital }\end{array}$ & $\begin{array}{l}\text { The plasma levels of angiotensin II of } \\
\text { patients infected by 2019-nCoV were } \\
\text { significantly higher than those of and } \\
\text { healthy individuals. In addition, the level of } \\
\text { angiotensin II in patients with nCoV-2019 } \\
\text { was strongly associated with viral load and } \\
\text { lung injury, suggesting that the imbalance of } \\
\text { the renin-angiotensin system (RAS) in } \\
\text { patients was caused by } 2019 \text {-nCoV and } \\
\text { enzyme-inhibiting drugs such as ACE } \\
\text { inhibitors and ARBs that balance RAS can be } \\
\text { used to treat patients infected with } 2019 \text { - } \\
\text { nCoV. }\end{array}$ & $\begin{array}{l}\text { Moderate quality } \\
\text { case series (JBI } \\
\text { critical appraisal } \\
\text { tool for case } \\
\text { series) }\end{array}$ \\
\hline $\begin{array}{l}\text { Fang et al., } \\
2020\end{array}$ & Correspondence & NA & $\begin{array}{l}\text { This is the main study related to the recent } \\
\text { discussion on the role of ACE in the } \\
\text { pathology of COVID-19. Based on this study, } \\
\text { WHO suggests the interruption of ibuprofen } \\
\text { use. } \\
\text { The study suggests that patients with heart } \\
\text { disease, hypertension or } \\
\text { diabetes, which are frequently treated with } \\
\text { medications that increase ACE-2, are at } \\
\text { increased risk of severe COVID-19 infection } \\
\text { and therefore should be monitored for ACE-2 } \\
\text { modulating medications, such as ACE } \\
\text { inhibitors or ARBs. }\end{array}$ & High risk \\
\hline $\begin{array}{l}\text { Guo et al., } \\
2020\end{array}$ & Case series & $\begin{array}{l}187 \text { patients with } \\
\text { COVID-19 from the } \\
\text { Seventh Hospital of } \\
\text { Wuhan City, China. } 63 \\
\text { (35.3\%) had some } \\
\text { cardiovascular } \\
\text { disease such as }\end{array}$ & $\begin{array}{l}\text { This study aimed to evaluate the association } \\
\text { of underlying CVD and myocardial injury } \\
\text { with fatal outcomes in patients with COVID- } \\
19 .\end{array}$ & $\begin{array}{l}\text { Good Quality } \\
\text { case series (JBI } \\
\text { critical appraisal } \\
\text { tool for case } \\
\text { series) }\end{array}$ \\
\hline
\end{tabular}




\begin{tabular}{|c|c|c|c|c|}
\hline $\begin{array}{c}\text { Author/ } \\
\text { year }\end{array}$ & Study Design & Sample & Main results & $\begin{array}{c}\text { Risk of bias/ } \\
\text { methodological } \\
\text { quality }\end{array}$ \\
\hline & & $\begin{array}{l}\text { hypertension, } \\
\text { coronary heart } \\
\text { disease, } \\
\text { cardiomyopathy, and } \\
52(27.8 \%) \text { had } \\
\text { myocardial damage } \\
\text { indicated by high } \\
\text { levels of troponin T } \\
\text { (TnT) }\end{array}$ & 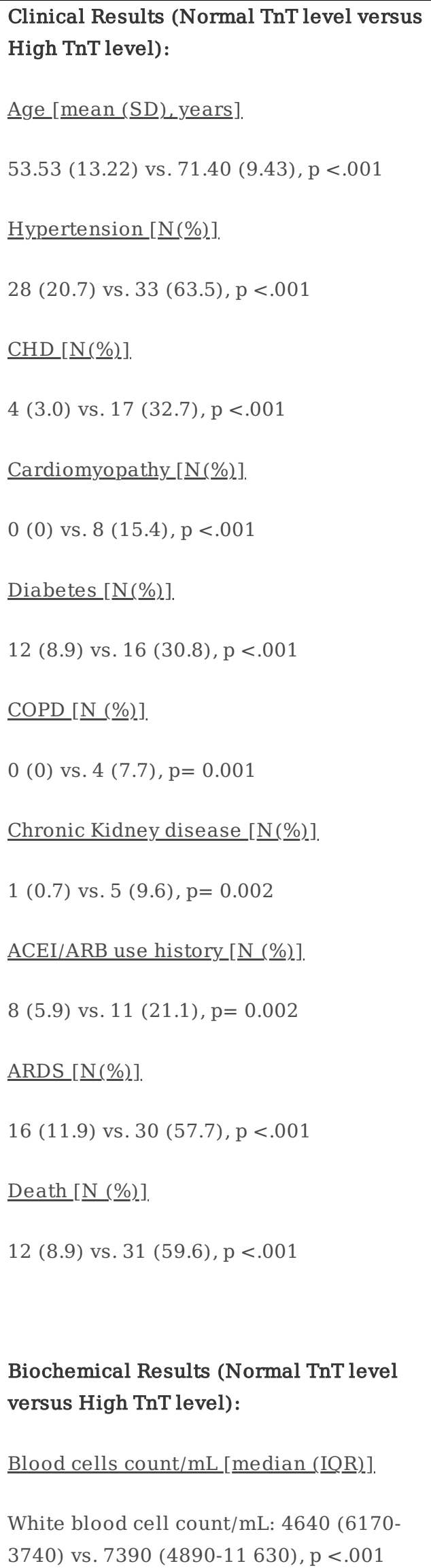 & \\
\hline
\end{tabular}

Page 21/31 


\begin{tabular}{|c|c|c|c|c|}
\hline $\begin{array}{c}\text { Author/ } \\
\text { year }\end{array}$ & Study Design & Sample & Main results & $\begin{array}{c}\text { Risk of bias/ } \\
\text { methodological } \\
\text { quality }\end{array}$ \\
\hline & & & 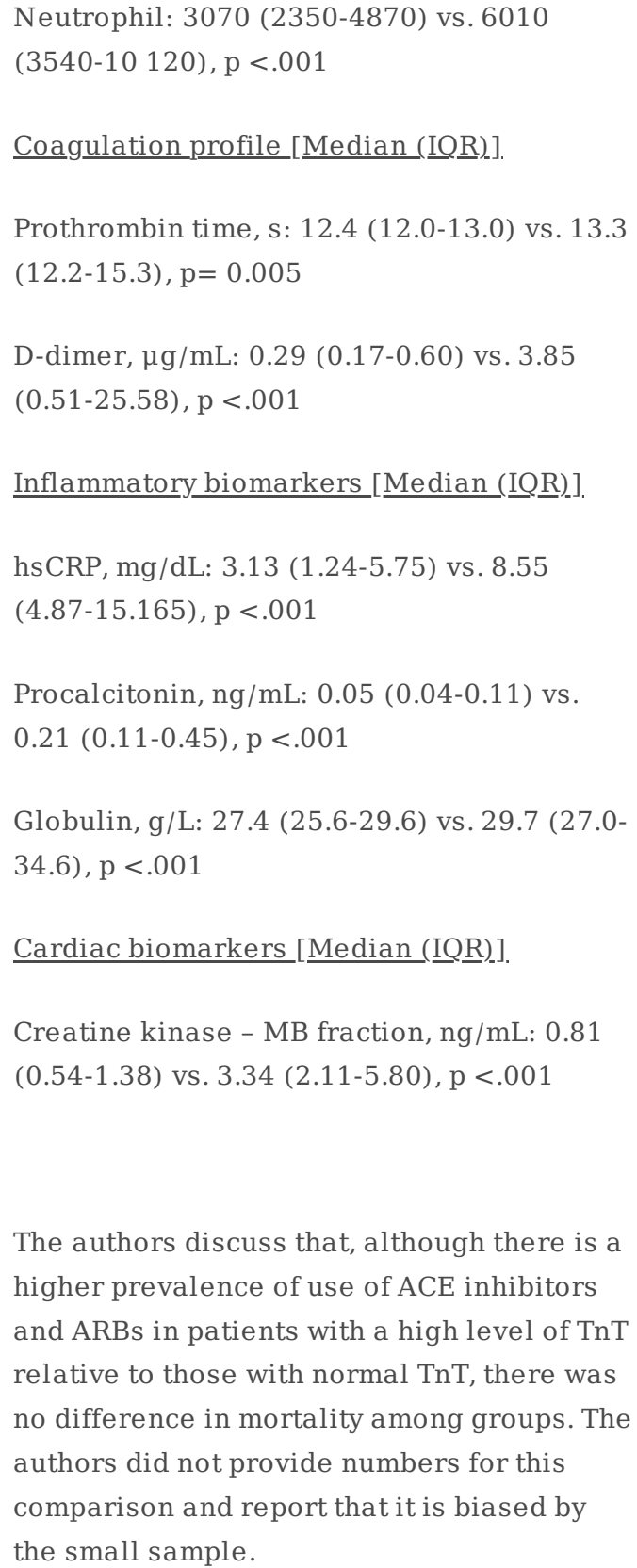 & \\
\hline
\end{tabular}




\begin{tabular}{|c|c|c|c|c|}
\hline $\begin{array}{c}\text { Author/ } \\
\text { year }\end{array}$ & Study Design & Sample & Main results & $\begin{array}{c}\text { Risk of bias/ } \\
\text { methodological } \\
\text { quality }\end{array}$ \\
\hline $\begin{array}{l}\text { Patel et al., } \\
2020\end{array}$ & Viewpoint & NA & $\begin{array}{l}\text { The study analyzes the mechanistic issues } \\
\text { related with ACE-2 and SARS-CoV2 } \\
\text { interaction, pointing out the lack of } \\
\text { consistent evidence regarding the use of } \\
\text { ACE inhibitors and ARBs in COVID-19 } \\
\text { patients. } \\
\text { According to the authors, there is concern } \\
\text { that the use of ACE inhibitors and ARBs will } \\
\text { increase the expression of ACE-2, resulting } \\
\text { in increased patient susceptibility to viral } \\
\text { host cell entry and propagation. On the other } \\
\text { hand, animal modelling studies have shown } \\
\text { that the SARS virus worsened lung injury } \\
\text { that was improved by treatment with ARBs, } \\
\text { suggesting that SARS-CoV exacerbates lung } \\
\text { injury by decreasing ACE-2 that can be } \\
\text { reversed by ARB treatment. } \\
\text { the } \\
\text { Society of Cardiology recommended not to } \\
\text { stop those medicines and that physicians } \\
\text { and patients should continue treatment with } \\
\text { because there is no clinical or scientific } \\
\text { evidence to suggest that treatment with ACE } \\
\text { inhibitors or ARBs should be discontinued } \\
\text { due to COVID-19 infection. } \\
\text { pinally, the authors postulate that despite } \\
\text { the lack of evidence, there have been } \\
\text { advocates for both the use and cessation of } \\
\text { ACE inhibitors and ARBs for COVID-19 in } \\
\text { path with cardiovascular comorbidities. } \\
\text { the authors highlight that the European }\end{array}$ & High risk \\
\hline
\end{tabular}




\begin{tabular}{|c|c|c|c|c|}
\hline $\begin{array}{c}\text { Author/ } \\
\text { year }\end{array}$ & Study Design & Sample & Main results & $\begin{array}{c}\text { Risk of bias/ } \\
\text { methodological } \\
\text { quality }\end{array}$ \\
\hline $\begin{array}{l}\text { Sparks at al., } \\
2020\end{array}$ & Perspective & NA & $\begin{array}{l}\text { The authors mentioned published data that } \\
\text { support the fact that there is no evidence to } \\
\text { support a clear relationship between } \\
\text { cardiovascular diseases and SARS-CoV-2 } \\
\text { pathogenicity. They explore the fact that } \\
\text { none of the reports have adjusted this } \\
\text { correlation for age or provided age- } \\
\text { stratified data for the hypertension and } \\
\text { mortality association to understand if this is } \\
\text { a robust finding. } \\
\text { They postulate that the complex relationship } \\
\text { between viral protein } \\
\text { binding to ACE-2, RAS components, and viral } \\
\text { pathogenicity } \\
\text { is not fully understood. Thus, they emphasize } \\
\text { that there is no good evidence to support } \\
\text { ACE inhibitors and ARBs harms or benefits. } \\
\text { hypertension will disrupt clinical care, } \\
\text { resulting in the need for extra visits, and } \\
\text { increase health care utilization, thus } \\
\text { disrupting attempts at social distancing. } \\
\text { The authors also suggested that stopping } \\
\text { ACE inhibitors and ARBs in asymptomatic, } \\
\text { stable patients with heart failure, kidney } \\
\text { disease, or }\end{array}$ & \\
\hline $\begin{array}{l}\text { Vaduganathan } \\
\text { et al., } 2020\end{array}$ & $\begin{array}{l}\text { Opinion/narrative } \\
\text { review }\end{array}$ & NA & $\begin{array}{l}\text { The authors discuss that there is some } \\
\text { concern about the fact that published studies } \\
\text { frequently report an increased risk of } \\
\text { COVID-19 aggravation and, consequently, } \\
\text { lung damage in patients with comorbidities, } \\
\text { such as hypertension. However, based on } \\
\text { recently published articles, the authors state } \\
\text { that advanced age emerges as the most } \\
\text { important factor for aggravation in COVID- } \\
\text { 19. However, no study has yet carried out } \\
\text { analyses corrected for age or other } \\
\text { confounding factors, which allow a risk to be } \\
\text { established. }\end{array}$ & High risk \\
\hline
\end{tabular}




\begin{tabular}{|c|c|c|c|c|}
\hline $\begin{array}{c}\text { Author/ } \\
\text { year }\end{array}$ & Study Design & Sample & Main results & $\begin{array}{c}\text { Risk of bias/ } \\
\text { methodological } \\
\text { quality }\end{array}$ \\
\hline & & & $\begin{array}{l}\text { The authors point out that only } 25 \text { to } 30 \% \text { of } \\
\text { treated hypertensive individuals use this } \\
\text { class of drugs and that studies designed to } \\
\text { assess the influence of RAAS inhibitors on } \\
\text { COVID-19 are needed. } \\
\text { Because ACE inhibitors and ARBs have } \\
\text { different effects on angiotensin II, the } \\
\text { primary substrate of ACE-2, the effects of } \\
\text { these agents on ACE-2 levels and activity } \\
\text { may be anticipated to differ. It has been } \\
\text { highlighted, based on animal and human } \\
\text { models, that some studies have shown that } \\
\text { there has been no increase in angiotensin } \\
\text { (1-7) production, including some studies that } \\
\text { have shown that ACE- } 2 \text { activity was not } \\
\text { different between individuals receiving ACE } \\
\text { inhibitors or ARBs and their untreated } \\
\text { controls. } \\
\text { Finally, the authors conclude that stopping } \\
\text { chronic treatment for cardiovascular disease } \\
\text { is dangerous and not recommended. They } \\
\text { also report that the change of } \\
\text { antihypertensive agent is not simple and } \\
\text { It is argued that there is a potential increase } \\
\text { in angiotensin II in individuals with COVID- } \\
\text { 19 and that it is related to lung damage. } \\
\text { Based on in vitro studies for other diseases, } \\
\text { the authors indicate that with continued viral } \\
\text { infection, there is a reduction in ACE- } 2 \text { in the } \\
\text { cell membrane. Down-regulation of ACE- } 2 \\
\text { activity in the lungs may facilitate the initial } \\
\text { neutrophil infiltration. So, there is a } \\
\text { The authors discuss that there is insufficient } \\
\text { data to transport the analyses in animal } \\
\text { models to humans and that there is still no } \\
\text { evidence of the effect of ACE-2 expression } \\
\text { on the human lung. }\end{array}$ & \\
\hline
\end{tabular}

Page 25/31 


\begin{tabular}{|c|l|l|l|l|}
\hline $\begin{array}{c}\text { Author/ } \\
\text { year }\end{array}$ & Study Design & Sample & Main results & $\begin{array}{c}\text { Risk of bias/ } \\
\text { methodological } \\
\text { quality }\end{array}$ \\
\hline & & & $\begin{array}{l}\text { that it can cause different effects in patients } \\
\text { with constant and stable therapeutic } \\
\text { regimen. }\end{array}$ & \\
\hline
\end{tabular}

2019-nCoV, 2019 novel Coronavirus; ACE, Angiotensin Converting Enzyme; ARB, Angiotensin Receptor Blocker; AT1R, Angiotensin Receptor 1; ARDS, acute respiratory distress syndrome; COVID-19, Coronavirus Disease, 2019; CHD: Coronary Heart Disease; COPD: Chronic Obstructive Pulmonary Disease; CRP, C-Reactive Protein; CVD, Cardiovascular Disease; RAAS, Renin-Angiotensin-Aldosterone-System; RBD, Receptor Binder Domain; SARS-CoV-2, Severe Acute Respiratory Syndrome Coronavirus 2; TnT: Troponin T; WHO, World Health Organization.

Table 1: Methodological quality according to JBI critical appraisal for Case Series. 


\begin{tabular}{|c|c|c|}
\hline Criterion & Judgement & Statement \\
\hline \multicolumn{3}{|r|}{ Liu et al., 2020} \\
\hline $\begin{array}{l}\text { Were there clear criteria for } \\
\text { inclusion in the case series? }\end{array}$ & Yes & All patients with COVID-19 in the Shenzhen Third People's Hospital \\
\hline $\begin{array}{l}\text { Was the condition measured in a } \\
\text { standard, reliable way for all } \\
\text { participants included in the case } \\
\text { series? }\end{array}$ & Yes & Throat swab and RT-PCR for confirmation of COVID-19 \\
\hline $\begin{array}{l}\text { Were valid methods used for } \\
\text { identification of the condition for all } \\
\text { participants included in the case } \\
\text { series? }\end{array}$ & Yes & RT-PCR \\
\hline $\begin{array}{l}\text { Did the case series } \\
\begin{array}{l}\text { consecutive } \\
\text { conselusion }\end{array} \\
\text { participants? }\end{array}$ & Yes & All cases in a prospective way \\
\hline $\begin{array}{l}\text { Did the case series have complete } \\
\text { inclusion of participants? }\end{array}$ & Unclear & $\begin{array}{l}\text { They declared complete inclusion (all patients). However, } 12 \text { is relatively } \\
\text { a small number in a pandemic. }\end{array}$ \\
\hline $\begin{array}{l}\text { Was there clear reporting of the } \\
\text { demographics of the participants in } \\
\text { the study? }\end{array}$ & Yes & Age, sex and different clinical criteria on admission \\
\hline $\begin{array}{l}\text { Was there clear reporting of clinical } \\
\text { information of the participants? }\end{array}$ & Yes & Initial symptoms \\
\hline $\begin{array}{l}\text { Were the outcomes or follow up } \\
\text { results of cases clearly reported? }\end{array}$ & Yes & Two tables with all the planned clinical and biochemical analysis. \\
\hline $\begin{array}{l}\text { Was there clear reporting of the } \\
\text { presenting } \\
\text { demographic information? }\end{array}$ & No & No data of prevalence or any other epidemiological data was described \\
\hline $\begin{array}{l}\text { Was the statistical analysis } \\
\text { appropriate? }\end{array}$ & $\begin{array}{c}\text { Not } \\
\text { Applicable }\end{array}$ & No statistical analysis for comparison \\
\hline \multicolumn{3}{|r|}{ Guo et al., 2020} \\
\hline $\begin{array}{l}\text { Were there clear criteria for } \\
\text { inclusion in the case series? }\end{array}$ & Yes & $\begin{array}{l}\text { Patients with COVID-19 who were diagnosed according to the interim } \\
\text { guidance of the World Health Organization from January 23, 2020, to } \\
\text { February 23, 2020, and who were either treated and discharged or died } \\
\text { during hospitalization }\end{array}$ \\
\hline $\begin{array}{l}\text { Was the condition measured in a } \\
\text { standard, reliable way for all } \\
\text { participants included in the case } \\
\text { series? }\end{array}$ & Yes & $\begin{array}{l}\text { The electronic medical records of the patients were reviewed by a trained } \\
\text { team of physicians who worked in Seventh Hospital of Wuhan City during } \\
\text { the epidemic period. }\end{array}$ \\
\hline $\begin{array}{l}\text { Were valid methods used for } \\
\text { identification of the condition for all } \\
\text { participants included in the case } \\
\text { series? }\end{array}$ & Yes & Guidance of the World Health Organization \\
\hline $\begin{array}{l}\text { Did the case series } \begin{array}{r}\text { have } \\
\text { consecutive } \\
\text { participants? }\end{array} \\
\end{array}$ & Yes & Data were collected in consecutive patients hospitalized with COVID-19 \\
\hline $\begin{array}{l}\text { Did the case series have complete } \\
\text { inclusion of participants? }\end{array}$ & No & $\begin{array}{l}\text { They excluded } 67 \text { discharged patients and } 2 \text { patients who died because of } \\
\text { incomplete data }\end{array}$ \\
\hline $\begin{array}{l}\text { Was there clear reporting of the } \\
\text { demographics of the participants in } \\
\text { the study? }\end{array}$ & Yes & Age, sex and different clinical and biochemical criteria on admission \\
\hline $\begin{array}{l}\text { Was there clear reporting of clinical } \\
\text { information of the participants? }\end{array}$ & Yes & Clinical and biochemical variables \\
\hline $\begin{array}{l}\text { Were the outcomes or follow up } \\
\text { results of cases clearly reported? }\end{array}$ & Yes & Two tables with all the planned clinical and biochemical analysis. \\
\hline $\begin{array}{l}\text { Was there clear reporting of the } \\
\text { presenting } \\
\text { demographic information? }\end{array}$ & No & No data of prevalence or any other epidemiological data was described \\
\hline
\end{tabular}




\begin{tabular}{l}
$\begin{array}{l}\text { Was the statistical analysis } \\
\text { appropriate? }\end{array}$ \\
\hline
\end{tabular}

Legend: COVID-19, Coronavirus Disease, 2019; RT-PCR, Real-Time Polymerase Chain Reaction.

Table 5: Clinical trials registered at ClinicalTrials.Gov as of March 31 ${ }^{\text {th }}, 2020$. 


\begin{tabular}{|c|c|c|c|c|}
\hline $\begin{array}{c}\text { NCT } \\
\text { number }\end{array}$ & $\begin{array}{l}\text { Type of } \\
\text { Strategy }\end{array}$ & Study Characteristics & Timeline & $\begin{array}{c}\text { Preliminary } \\
\text { Results }\end{array}$ \\
\hline NCT04312009 & Treatment & $\begin{array}{l}\text { Title: Losartan for Patients With COVID-19 Requiring Hospitalization } \\
\qquad \text { Country: U.S.A. } \\
\text { Study design: Phase II, parallel, quadruple blind RCT } \\
\text { Status: Not yet recruiting } \\
\text { Participants: Adults with confirmed SARS-CoV-2 infection or with upper } \\
\text { respiratory infection with recent exposure to COVID-19 patient and respiratory } \\
\text { symptoms ( } \mathrm{n}=200) \\
\text { Intervention: Losartan } \\
\text { Comparator: Placebo } \\
\text { Primary outcome: Sequential Organ Failure Assessment (SOFA) Respiratory } \\
\text { Score }\end{array}$ & $\begin{array}{l}\text { First posted: } \\
\text { 17/03/2020 } \\
\text { Estimated study } \\
\text { start date: } \\
\text { 16/03/2020 } \\
\text { Estimated primary } \\
\text { completion date: } \\
\text { 01/03/2021 } \\
\text { Estimated primary } \\
\text { completion date: } \\
01 / 04 / 2021\end{array}$ & No \\
\hline NCT04311177 & Treatment & $\begin{array}{l}\text { Title: Losartan for Patients With COVID-19 Not Requiring Hospitalization } \\
\qquad \text { Country: U.S.A. } \\
\text { Study Design: Phase II, parallel, quadruple blind RCT } \\
\text { Status: Not yet recruiting } \\
\text { Participants: Adults with confirmed SARS-CoV-2 infection or with upper } \\
\text { respiratory infection with recent exposure to COVID-19 patient ( } \mathrm{n}=478) \\
\text { Intervention: Losartan } \\
\text { Comparator: Placebo } \\
\text { Primary outcome: Hospital admission }\end{array}$ & $\begin{array}{l}\text { First posted: } \\
\text { 16/03/2020 } \\
\text { Estimated study } \\
\text { start date: } \\
\text { 09/02/2020 } \\
\text { Estimated primary } \\
\text { completion date: } \\
\text { 01/04/2021 } \\
\text { Estimated primary } \\
\text { completion date: } \\
\text { 01/04/2021 }\end{array}$ & No \\
\hline NCT04287686 & Treatment & $\begin{array}{l}\text { Title: Recombinant Human Angiotensin-converting Enzyme } 2 \text { (rhACE2) as a } \\
\text { Treatment for Patients With COVID-19 } \\
\text { Country: China } \\
\text { Study Design: Parallel, open label RCT } \\
\text { Status: Withdrawn (Reason: Without CDE approval) } \\
\text { Participants: Adults with confirmed diagnosis of COVID-19 and signs of } \\
\text { respiratory distress }(n=24) \\
\text { Intervention: rhACE2 + standard of care } \\
\text { Comparator: Placebo + standard of care } \\
\text { Primary outcome: Time course of body temperature (fever) and viral load over } \\
\text { time }\end{array}$ & $\begin{array}{l}\text { First posted: } \\
\text { 27/02/2020 } \\
\text { Estimated study } \\
\text { start date: } \\
02 / 2020 \\
\text { Estimated primary } \\
\text { completion date: } \\
\text { 04/2020 } \\
\text { Estimated study } \\
\text { completion date: } \\
04 / 2020\end{array}$ & No \\
\hline NCT04272710 & Treatment & $\begin{array}{l}\text { Title: Prognostic Factors in COVID-19 Patients Complicated with Hypertension } \\
\text { Country: China } \\
\text { Study Design: Retrospective Cohort } \\
\text { Status: Withdrawn (Reason: Similar projects have been registered, and it need to } \\
\text { be withdrawn) } \\
\text { Participants: Adults with confirmed diagnosis of hypertension and COVID-19 and } \\
\text { signs of respiratory distress ( } \mathrm{n}=\mathrm{NA} \text { ) } \\
\text { Intervention: ACE inhibitors treatment } \\
\text { Comparator: No ACE inhibitors treatment } \\
\text { Primary outcome: Occupancy rate in the intensive care unit, mechanical } \\
\text { ventilation, and death }\end{array}$ & $\begin{array}{c}\text { First posted: } \\
\text { 17/02/2020 } \\
\text { Estimated study } \\
\text { start date: } \\
\text { 25/01/2020 } \\
\text { Estimated primary } \\
\text { completion date: } \\
31 / 03 / 2020 \\
\text { Estimated study } \\
\text { completion date: } \\
30 / 04 / 2020\end{array}$ & No \\
\hline
\end{tabular}




\begin{tabular}{|c|c|c|c|c|}
\hline $\begin{array}{c}\text { NCT } \\
\text { number }\end{array}$ & $\begin{array}{l}\text { Type of } \\
\text { Strategy }\end{array}$ & Study Characteristics & Timeline & $\begin{array}{c}\text { Preliminary } \\
\text { Results }\end{array}$ \\
\hline NCT04318301 & Treatment & 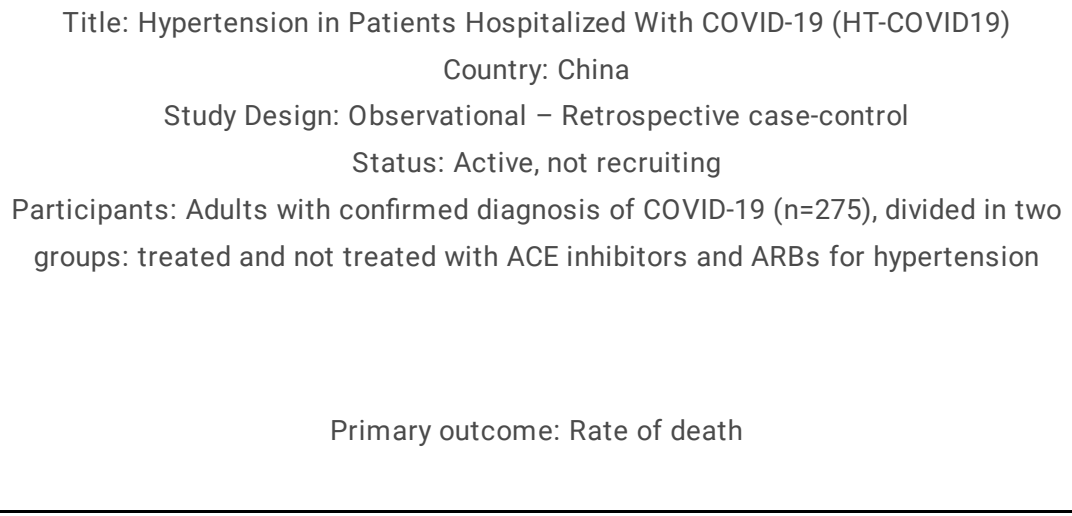 & $\begin{array}{c}\text { First posted: } \\
\text { 23/03/2020 } \\
\text { Estimated study } \\
\text { start date: } \\
\text { 21/03/2020 } \\
\text { Estimated primary } \\
\text { completion date: } \\
\text { 28/03/2020 } \\
\text { Estimated study } \\
\text { completion date: } \\
30 / 03 / 2020 \\
\end{array}$ & No \\
\hline NCT04328012 & Treatment & $\begin{array}{l}\text { Title: Comparison Of Therapeutics for Hospitalized Patients Infected With SARS- } \\
\text { CoV-2 In a Pragmatic aDaptive randoMizED Clinical Trial During the COVID-19 } \\
\text { Pandemic (COVID MED Trial) (COVID MED) } \\
\text { Country: USA } \\
\text { Study Design: Parallel, quadruple blind, phase II/III RCT } \\
\text { Status: Not yet recruiting } \\
\text { Participants: Hospitalized adults with confirmed diagnosis of COVID-19 ( } \mathrm{n}=4,000) \\
\text { Intervention: Lopinavir/ritonavir + standard care/ hydroxychloroquine + standard } \\
\text { care/ losartan + standard care } \\
\text { Comparison: Placebo + standard care } \\
\text { Primary outcome: Severity of disease }\end{array}$ & $\begin{array}{c}\text { First posted: } \\
31 / 03 / 2020 \\
\text { Estimated study } \\
\text { start date: } \\
\text { 01/04/2020 } \\
\text { Estimated primary } \\
\text { completion date: } \\
\text { 21/01/2021 } \\
\text { Estimated study } \\
\text { completion date: } \\
01 / 04 / 2021\end{array}$ & No \\
\hline NCT04318418 & Treatment & $\begin{array}{l}\text { Title: ACE Inhibitors, Angiotensin II Type-I Receptor Blockers and Severity of } \\
\text { COVID-19 (CODIV-ACE) } \\
\text { Country: Italy } \\
\text { Study Design: Observational - Case control } \\
\text { Status: Not yet recruiting } \\
\text { Participants: Hospitalized patients with confirmed diagnosis of COVID-19 } \\
(\mathrm{n}=5,000) \text {, divided in case and control groups: patients who develop and do not } \\
\text { develop severe COVID-19, respectively } \\
\text { Exposure: ARB or ACE inhibitors } \\
\text { Primary outcome: Severe COVID-19 }\end{array}$ & $\begin{array}{l}\text { First posted: } \\
\text { 24/03/2020 } \\
\text { Estimated study } \\
\text { start date: } \\
\text { 23/03/2020 } \\
\text { Estimated primary } \\
\text { completion date: } \\
\text { 10/04/2020 } \\
\text { Estimated study } \\
\text { completion date: } \\
30 / 04 / 2020\end{array}$ & No \\
\hline
\end{tabular}

Legend: ACE, Angiotensin-Converting Enzyme; ARBs, Angiotensin II Receptor Blockers; CDE, Center for Drug Evaluation; COVID-19, Coronavirus Disease 2019; NA, not available; RCT, Randomized Controlled Trial; SARSCoV-2, Severe Acute Respiratory Syndrome Coronavirus-2.

\section{Figures}




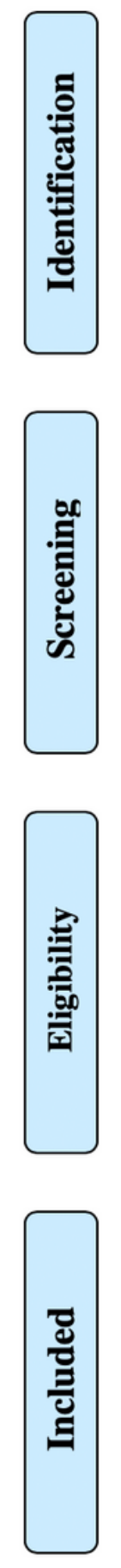

$$
\begin{gathered}
\text { Records identified through database } \\
\text { searching } \\
(\mathrm{n}=38-\text { Medline (via PubMed) }) \\
(\mathrm{n}=20-\text { Embase })
\end{gathered}
$$

Additional records identified through other sources ( $\mathrm{n}=7$ - ClinicalTrials.gov) ( $\mathrm{n}=2$ - Manual Search)

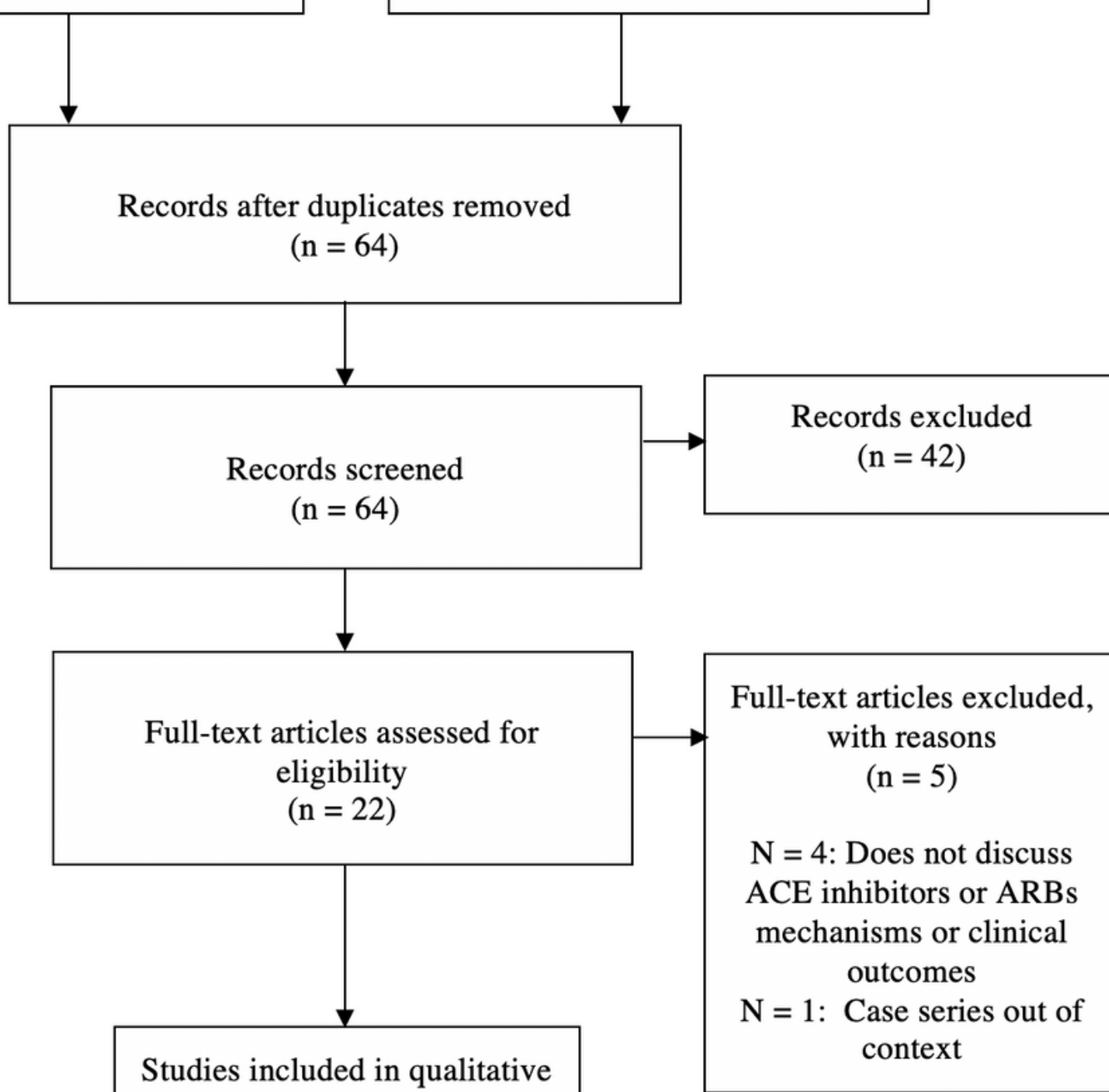

Figure 1

PRISMA flowchart of the screening process 